\title{
Lithofacies and Sedimentation of Organic Matter in Fine Grained Rocks of Nanggulan Formation in Kulon Progo, Yogyakarta
}

\author{
Hendra Amijaya*, Najibatul Adibah, and Ahmad Z.A. Ansory \\ Department of Geological Engineering, Faculty of Engineering, Gadjah Mada University, Yogyakarta, Indonesia
}

\begin{abstract}
Fine grained rocks especially shale play a significant role in shale hydrocarbon system. Research on Eocene Nanggulan shale becomes an interest lately since this shale is considered as prospective interval for shale gas source. It potentially contains significant organic matter because coaly sediment is found in this formation as well. Nanggulan Formation fine grained rocks was deposited in various depositional environment from estuary - shallow marine. This paper integrates the result of lithofacies and depositional environment analysis with organic geochemical data to understand the sedimentation process of organic matter. Samples were taken from cores. The result of 14 geochemically analysed samples shows Total Organic Carbon (TOC) content between 0.36-1.00\% for fin e grained rocks (shales) and $12.80 \%$ for coaly shales. Nine samples are categorized as fair and 2 samples are categorized as good source rock. The depositional environment of Nanggulan Formation sediment, which was shallow marine at Late Eocene and estuary (salt marsh) at Early Eocene, produced sediment with higher TOC. Whereas the deposition of sediment in estuary (tidal flat) at Middle Eocene produced lower content of TOC. Vulcanic activity at Middle Eocene also caused less organic material preservation because it produced abundant inorganic material.
\end{abstract}

Keywords: Fine-grained rock · Lithofacies · Organic matter · Nanggulan Formation $\cdot \mathrm{Ku}-$ lon Progo.

\section{INTRODUCTION}

Indonesia is a country which is indicated having significant shale gas potential. This is supported by data from Oil and Gas Directorate General, Ministry of Energy and Mineral Resources that stated the total speculative shale gas resource in Indonesia reached the number of 574 TCF (Wagimin, 2014). Study on fine grained rocks especially in petroleum system point of view becomes very important. Fine grained rocks especially shale play a significant role in shale hydrocarbon system.

Shale of Nanggulan Formation is one of Eocene rocks is widely exposed in south part of Central Java. Eocene Nanggulan shale becomes an interest lately since this shale is considered

\footnotetext{
*Corresponding author: H. AMIJAYA, Department of Geological Engineering, Gadjah Mada University. Jl. Grafika 2 Yogyakarta, Indonesia 55281. E-mail: hamijaya@ugm.ac.id
}

as prospective interval for shale gas source. It potentially contains significant organic matter because coaly sediment is found in this formation as well. However, information on the geochemical characteristic of this formation is relatively limited.

Nanggulan Formation in general contains mudstone with limonite concretion, sandy marl, limestone, lignite and sandstone (Rahardjo et al., 1995). Winardi et al. (2013) classified Nanggulan shale as poor - very good potential source rock with some limitations in maturity level. This paper is aimed to understand the sedimentation process of organic matter in the fine grained rocks of Nanggulan Formation using the variation of Total Organic Carbon (TOC) which indicates the amount of organic carbon in the formation. 


\section{Methodology}

The analysis was executed by composing 2 core data taken from Pandawarejo, Girimulyo and Banjararum, Nanggulan in Kulon Progo (named Nanggulan 1 and 2, see Figure 1). Lithofacies analysis was conducted by describing facies parameters such as geometry, lithology, sedimentary structure, and fossil content. Determination of lithofacies association was based on the sedimentary rock succession in transitional to shallow marine environment by Nichols (2009).

TOC analysis was done using a LECO sulfur analyzer at PT. Geoservices Ltd. Geological \& Laboratory Services Division. This analysis was using 1 gram rock powder each of 14 finegrained rock samples especially shales which had previously been cleared from calcareous components using $\mathrm{HCl}$ solution. The TOC value was then matched with lithofacies characteristics and depositional environment interpretation.

\section{Results AND Discussion}

\section{Lithofacies}

From detailed core analysis as shown in Figure 2. 11 different facieses were defined, which are:

a. Laminated Sandstone Facies; Brownish grey fine sand facies with subangularsubrounded grains, well-sorted, grainsupported, low to medium hardness, laminated structure, and consists of quartz, plagioclase, mollusk fragments, and fine sedimentary material.

b. Massive Sandstone Facies; Light grey finecoarse sand facies with subangular grains, poorly to well-sorted, brittle, massive sedimentary structure, and contains quartz, feldspars, and occasional mollusk and macro-foraminifer fragments.

c. Wavy-Flaser Sandstone Facies; Light grey fine-coarse sand facies with subangular grains, poorly to medium-sorted, low hardness, medium cementation, wavyflaser and parallel bedding sedimentary structure, and composed of quartz, feldspars, mica, clay minerals, and mollusk and macro-foraminifer fragments.

d. Massive Claystone Facies; Grey clay facies with massive sedimentary structure and composed of clay minerals, quartz, feldspars, and occasional carbon flack and mollusk fragments. Generally, massive claystone facies is a non-calcareous facies.

e. Massive Mudstone Facies; Calcareous grey facies with clay-sized matrix and sand to gravel fragments, brittle, poorly-sorted, and lenticuler sedimentary structure. The matrix consists of clay minerals, while fragments are some mollusks and nummulites.

f. Mollusk-rich Mudstone Facies; Calcareous grey facies with silt-sized matrix and sand to gravel (1-40 mm) fragments, poorlysorted, and matrix-supported. The matrix consists of silt-sized sedimentary materials and calcareous minerals, while fragments are some mollusks, nummulites, discocyclina, quartz, and feldspar.

g. Floatstone Facies; Calcareous dark grey facies with silt-sized matrix and more than $10 \%$ sand-gravel fragments, mudsupported, and contains calcareous materials and macro-foraminifers.

h. Crystalline Carbonate Facies; Calcareous grey mud facies, crystalline, and consists of calcareous minerals, mollusca fragments, and calcite vein.

i. Coal Facies; Black lithology facies with dull luster, high hardness, and massive sedimentary structure. The coal contains face and butt cleat.

j. Interbedded Claystone and Sandstone Facies; Dark grey facies. Sandstone consists of very fine-coarse sand materials with occasional clay matrix, poorly-well sorted, and contains lithic, clay minerals, and mollusk fragments. Claystone consists of clay-sized materials and massive structure.

k. Lenticular Mudstone Facies; Calcareous dark grey facies with clay to silt-sized matrix and fine-coarse sand fragments, poorlysorted, lenticuler and flaser sedimentary structure, and composed of quartz, feldspars, and mollusk fragments.

Based on those lithofacies, five facies associations were classified related to transitional - shallow marine depositional environment, which are: 


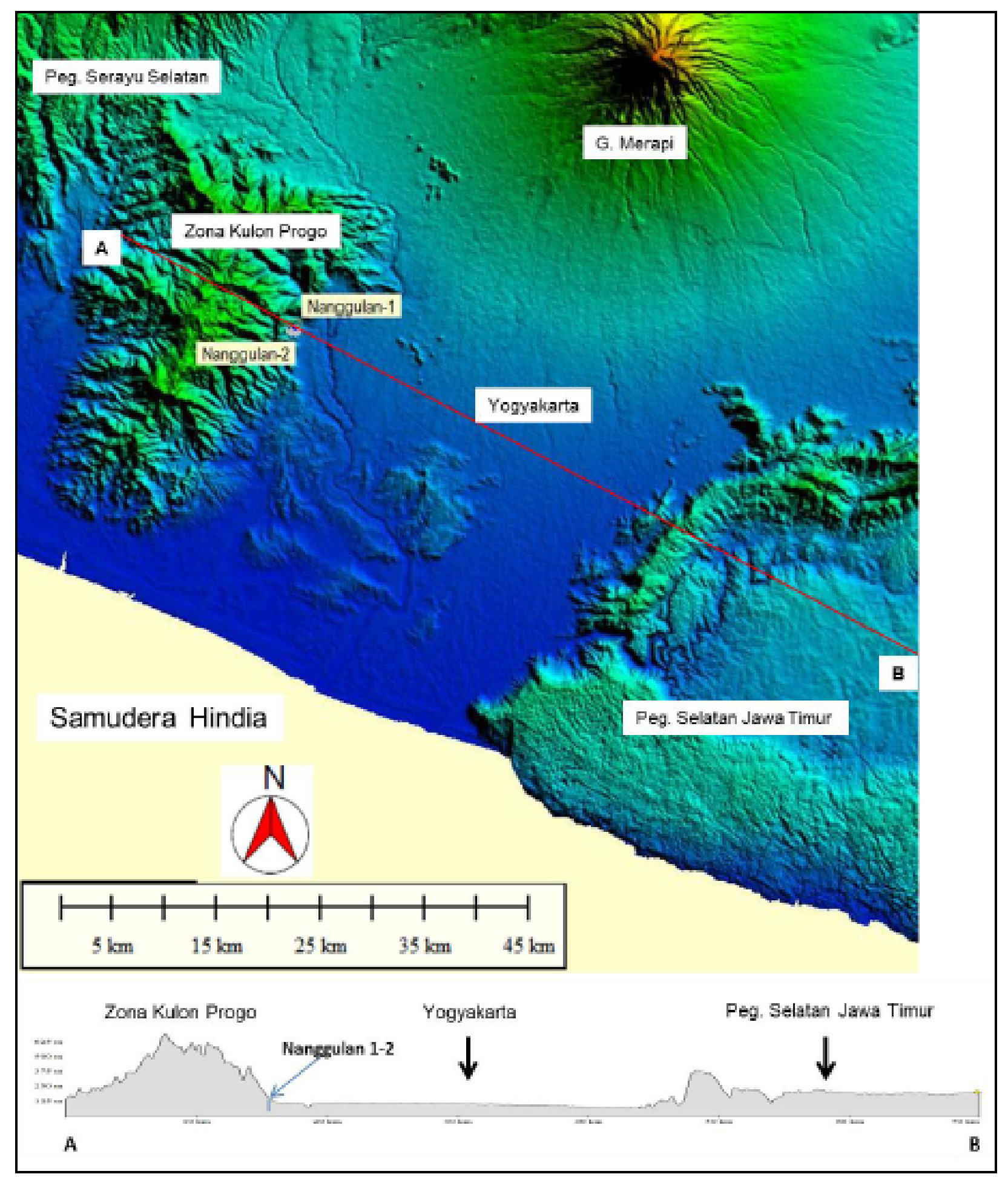

Figure 1: Location of Nanggulan 1 and Nanggulan 2 in Kulon Progo where sampling was conducted. 


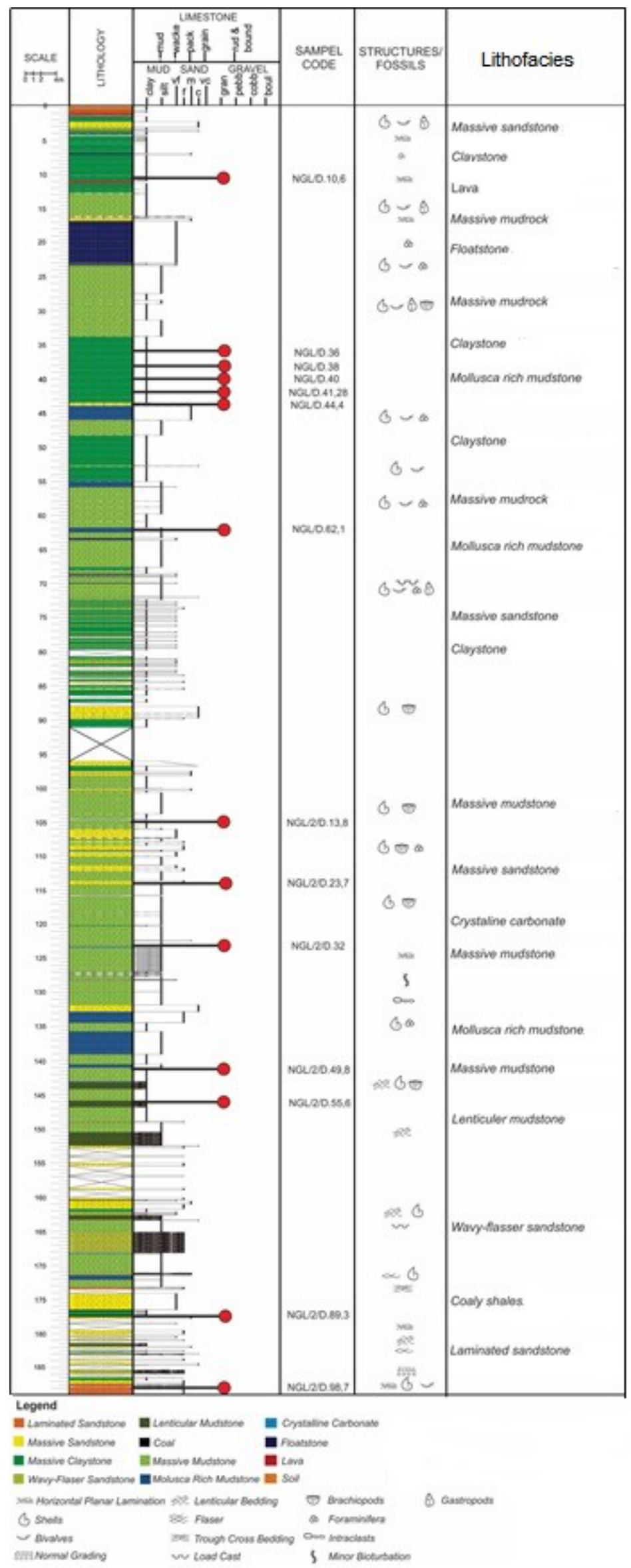

Figure 2: Lithological column of Nanggulan Formation and TOC analysis sampling location. 
a. Upper Flow Regime (UFR) Sand Flats Facies Association

This facies association is made of laminated sandstone, massive sandstone, wavy-flaser sandstone, lanticular mudstone, and massive claystone facies. Laminated sandstone facies consists of fine sand materials, which indicates an environment with fair to high depositional energy and specific current velocity (Boggs, 2006). Based on Hjulstrom diagram (in Nichols, 2009), fine-sand materials can be transported with bed-load mechanism.

The sedimentary structure in wavy-flaser sandstone facies refers to depositional processes affected by a constantly changing hydraulic, while the structure in lenticular mudstone facies indicates sedimentation in a tide-influenced environment.

UFR sand flats facies association is a part of braided channels in a wide estuary. Those channels are tributing seaward. This facies is located in the meeting point of fluvial and tidal energy in a tide-dominated estuary. Sediments from this facies is made of fine sandstone with parallel lamination structure (Dalrymple and Davis, 2012).

UFR sand flats also covers a part of the inner-most tidal channel that commonly are meandering channels (Nichols, 2009). In this facies, there are two kinds of current affecting the sedimentation; they are fluvial and tidal-current. Fluvial current produced sand-sized sediment deposits, while tidal current resulted in clay-sized deposits. These mechanisms enabled interbedded sandstone and claystone to be formed.

\section{b. Salt Marsh Facies Association}

From core analysis, salt marsh facies is represented by coal and massive claystone facies. Some bedding fissility is shown in the claystone and it also consists of noncalcareous composition. The coal is black, hard, and has cleats.

Salt marsh is a part of estuary beside tidal channels and tidal bar which situated closer to the land / continent. This facies is dominated by fine-sized sediment with a little sand components and organic materials. Silt-sized sediment is mostly composed of suspended organic materials; some of them are from the in-situ plants in the marsh itself. Deposition in salt marsh is controlled by organic activity rather than sedimentology processes (Dalrymple and Davis, 2012).

c. Tidal Flats Facies Association

Tidal flats facies association is dominated by massive sandstone and wavy-flaser sandstone facies in the lower part, and develops to massive mudstone, interbedded claystone and sandstone, and massive claystone facies.

d. Offshore Transition Facies Association

Offshore transition facies association is mostly dominated by massive mudstone facies with some mollusk-rich mudstone, massive claystone, crystaline carbonate, and massive sandstone facies.

From core analysis, it is known that the mollusk-rich mudstone and massive mudstone facies have extremely-abundant mollusk fragments and macro-foraminifers, pointing to a shallow marine environment with high depositional energy. Crystalline carbonate facies indicates a dominant marine influence in this environment.

e. Offshore Facies Association

Offshore facies association is the outermost part of shallow marine environment (Nichols, 2009). The association is dominated by massive mudstone dan floatstone facies with some massive claystone dan massive sandstone facies interbeds.

Massive mudstone facies domination with a little massive sandstone interbeds leads us to a depositional environment with low energy situated in the marine. Floatstone facies with bunches of mollusk fragments and macro-foraminifers indicates that the facies association was formed near to carbonate platform.

\section{Organic matter content and its sedimentation}

The TOC values are between 0.43 to $1.00 \mathrm{wt} . \%$ in the shale, and $12.78 \mathrm{wt} . \%$ on coaly-shales. Based on TOC content analysis, there are potentially 3 samples categorized as poor source rock, 9 samples are categorized as fair potential source rock, and 2 other samples with TOC 
$>1$ wt. $\%$ considered as good potential to produce hydrocarbons (see Table 1 ).

Table 1: Total Organic Carbon (TOC) content of fine grained sediments studied.

\begin{tabular}{clrc}
\hline No. & Sample ID & TOC (wt.\%) & $\begin{array}{c}\text { Source Rock } \\
\text { Quality* }\end{array}$ \\
\hline 1 & NGL/ D. 10,6 & 0.53 & Fair \\
2 & NGL/ D. 36 & 0.61 & Fair \\
3 & NGL/ D. 38 & 0.97 & Fair \\
4 & NGL/ D. 40 & 0.92 & Fair \\
5 & NGL/ D. 41,28 & 1.00 & Good \\
6 & NGL/ D. 44,4 & 0.89 & Fair \\
7 & NGL/ D. 62,1 & 0.43 & Poor \\
8 & NGL/ 2/ D. 13,8 & 0.41 & Poor \\
9 & NGL/ 2/ D. 23,7 & 0.67 & Fair \\
10 & NGL/ 2/ D. 32 & 0.36 & Poor \\
11 & NGL/ 2 / D. 49,8 & 0.78 & Fair \\
12 & NGL/ 2/ D. 55,6 & 0.86 & Fair \\
13 & NGL/ 2/ D. 89,3 & 12.78 & Excellent \\
14 & NGL/ 2/ D. 98,7 & 0.65 & Fair \\
\hline
\end{tabular}

*According to Peters \& Cassa (1994)

Sample NGL/D.38; NGL/D.40; NGL/ D.41,28; NGL/D.44,4 have a good TOC ranging $0.89-1.00$ wt.\% which indicates a good organic matter preservation. Based on the characteristics of lithology, this shale facies has an association with shallow marine depositional environment in offshore section. This depositional environment is sufficient to support the preservation of organic material, resulting a good TOC shale deposit.

In the other hand, TOC value from samples NGL/2/D.13,8; NGL/2/D.23,7; NGL/2/ D.32 is only about $0.36-0.67$ wt.\% which indicates poor organic matter preservation environment. Based on depositional environment interpretation, this samples was taken from estuary deposit. This environment was not suitable for organic matter preservation due to the influence of tidal current. The increasing volcanic activity, known from the presence of volcanic material components in the rocks samples such as pyrite, quartz, feldspar and abundant tuff, was also disturbing the accumulation of organic rich material and decreasing percentage of TOC content in the rock.

Samples NGL/2/D.49,8; NGL/2/D.55,6 and NGL/2/D.89,3 have TOC value of 0.78 wt.\%, 0.86 wt. $\%$ and 12.78 wt. $\%$, respectively. Sample NGL/2/D.89,3 is coaly shales which was de- posited at estuary mangrove swamp, while NGL/2/D.98,7, which has approximately 0.65 wt. $\%$ TOC content, was deposited in tidaldominated estuary channel. The later depositional environment is unfavorable for organic matter preservation and has a low percentage of TOC due to the high water circulation rate which hindering the organic-rich materials to accumulate. Besides that, the abundant supply of inorganic material was also lowering the preservation of organic matter. Geological conditions such as depositional environment as mention above affecting the degree of organic matter preservation. Low energy environment, anoxic, and less supply of inorganic material will be condusive environment for organicrich materials, which has potential to produce hydrocarbons, to be deposited.

In general, organic-rich shale which was formed during Late Eocene was deposited in shallow marine to open marine environment. This is an area that is free from volcanic debris supply and supports the development of anoxic environment that is good for TOC-rich rocks to accumulate. The depositional environment during Early Eocene - Middle Eocene was stream-affected estuary. This environment is actually good for the organic matter preservation, but the discovery of volcanic material supply showed that volcanic activity was quite affecting for the development of a good source rock. Mangrove swamp (estuary) depositional environment in this era was still favourable for the formation of organic material rich shale with thin coal inserts. But, this depositional environment was quite limited (see Heidrick and Marliyani, 2006), so that shale layer could not widely spread.

\section{CONCLUSIONS}

a. The Nanggulan Formation, Kulon Progo can be divided into 11 lithofacies with five facies association. Succession of lithofacies consist of Laminated sandstone facies, Massive sandstone facies, Flaser-Wavy sandstone facies, Massive claystone facies, Massive mudstone facies, Molusca rich mudstone facies, Floatstone facies, Crystalline carbonate facies, Coal facies, Claystone and sandstone interbedded facies, as well as Lenticular mudstone facies. Those associations are Upper 
Flow Regime (UFR) Sand Flats, Salt Marsh, Tidal Flats, Offshore Transition, and Offshore. Depositional environment of Nanggulan Formation starts from fluvial, tidal dominant estuarine to shallow marine. In general, depositional environment is deepening. Deposition process in the fluvial and estuarine influenced by river flow and tidal currents.

b. Fine grained sediment of Nanggulan Formation has sufficient quantity of organic material to produce hydrocarbons with TOC values in coaly shales and shales ranging from $0.36-1.00 \mathrm{wt} . \%$ and 12.78 wt.\%, respectively. Depositional environment is playing a big role in depositing the organic-rich materials, due to the fact that Nanggulan Formation, which was deposited in several environment such as shallow marine (offshore) during Late Eocene, estuaries (mangrove swamp) during Early Eocene, and tidal flat estuaries during Middle Eocene, has various value of TOC. The first two environments have greater value compared to the later one. Intensive volcanic activity played role in declining the TOC value during Middle Eocene, due to abundant supply of inorganic materials.

\section{ACKNOWLEDGEMENTS}

Authors thank PT. Bukit Energy for their cooperation in drilling and sampling activity.

\section{REFERENCES}

Boggs, S. J. (2006) Principles of Sedimentology and Stratigrafi, 4th Ed., Merill Publishing Company, Colombus, 662p.

Dalrymple, R.W., and Davis, R.A. (2012) Principles of Tidal Sedimentology, Springer Science and Business Media B.V., 621p.

Heidrick, T.L. and Marliyani, G.I. (2006) Nanggulan tectonostratigraphy. Geological Engineering FTUGM, 8p, (unpublished).

Nichols, G. (2009) Sedimentology and Stratigraphy, Wiley - Blackwell, United Kingdom. 419p.

Peters, K.E. and Cassa, M.R. (1994) Apllied Source Rock Geochemistry. In L. B. Magoon dan W.G. Dow, eds, The Petroleum System-From Source to Trap, AAPG Memoir 60, Tulsa: American Assosiation of Petroleum Geologist, p. 93-120.

Rahardjo, W., Sukandarrumidi, and Rosidi, H.M.D. (1995) Peta Geologi Lembar Yogyakarta, Jawa, Pusat Penelitian dan Pengembangan Geologi, Bandung.

Wagimin, N. (2014) Unconventional Oil \& Gas Development in Indonesia, Workshop Migas Non Konvensional, Directorate General Oil and Gas, Ministry of Energy and Mineral Resources, Presentation.

Winardi, S., Toha, B., Imron, M., and Amijaya, D.H. (2013) The Potential of Eocene Shale Nanggulan Formation as A Hydrocarbon Source Rock. Indonesian Journal of Geology 8: 13-23. 